McLaren, Peter (writer) \& Wilson, Miles (illustrator) (2019). Breaking free. The life and times of Peter McLaren, radical educator. Myers Education Press.

Not being allowed to read comics during my childhood, it is unsurprising that I have ever since enjoyed reading them and that I was attracted to this comic book about a critical pedagogue, Peter McLaren. The book is an attempt to further popularise McLaren's astonishingly prolific writings and to initiate especially younger readers who may be unfamiliar with his work and life. Undoubtedly, author Peter McLaren and illustrator Miles Wilson (a young artist and filmmaker who is pursuing a Master's degree in film editing) had fun putting this entertaining, yet controversial, book together.

The autobiographical subject of the book deserves a brief introduction. On the surface, Peter McLaren's (born 1948) biography reads fairly standard for any outstanding academic. He is a Canadian scholar who has authored and edited more than 40 books and hundreds of scholarly articles and chapters. McLaren left Canada in 1985 to teach at Miami University where he worked with Henry Giroux, another well-known critical pedagogue. Later appointments were at University of California, Los Angeles (UCLA), and Chapman University. At present, McLaren serves as Distinguished Professor at Chapman University, where he is also CoDirector of the Paulo Freire Democratic Project. He is also Emeritus Professor at UCLA and Miami University of Ohio, amongst other impressive accomplishments and accolades (see McLaren and Jandrić, 2014).

It is, however, less standard that McLaren also happens to be a Marxist humanist and a critical pedagogue. The book cover immediately gives this away: the top part of the suitably colourful front cover shows Mount Rushmorelike some of McLaren's hero(ine)s: Karl Marx, Paulo Freire, Angela Davis and Che Guavara. While this is not the place to review McLaren's massive oeuvre, it is useful to briefly refer to some of his key works, if only to ascertain that we are dealing with a serious yet iconoclastic educationist. McLaren taught working-class immigrant and minority group children in an inner-city elementary school in Toronto's notoriously violent Jane-Finch Corridor from 1974-1979. Cries from the Corridor, McLaren's book about his teaching experiences, was one of the top ten bestselling books in Canada in 1980 and initiated a country-wide debate on inner-city schools. Later, McLaren transformed his earlier work into perhaps his most famous book, Life in Schools. An Introduction to Critical Pedagogy in the Foundations of Education which is currently in its sixth edition. In-between the two books, McLaren also transformed himself "from a liberal humanist... to a Marxist humanist" (McLaren, 2003, p. xxxi). In 2006, the right-wing Bruin Alumni Association identified McLaren as the "most dangerous professor at UCLA", placing him on the top of a list of 30 left-wing professors who became known as "the dirty thirty" (Fassbinder \& McLaren, 2006; McLaren, 2021).

McLaren's first major scholarly publication, Schooling as a ritual performance. Towards a political economy of educational symbols and gestures (first published in 1986), was based on his PhD dissertation. From around 1994, McLaren broadened the scope of his writing from being an educational theorist (whose writings were largely directed at schooling) to additionally being a critical political economist. McLaren has written much about Freire and is strongly influenced by the Brazilian educationist. Both authors exemplify the inextricable interrelatedness of continual theorisation with critical praxis.

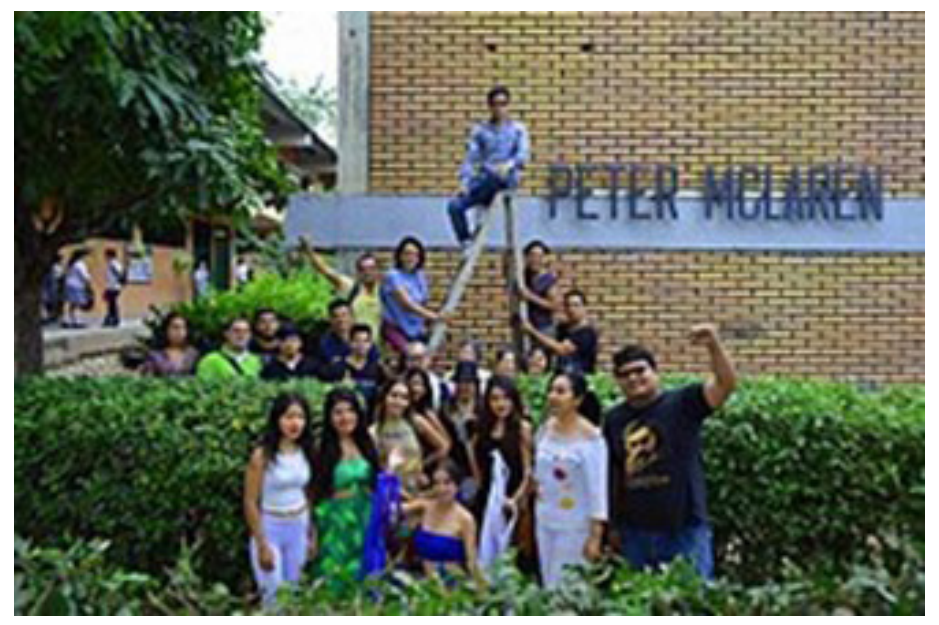

Figure 1: A Teachers College building (in La Escuela Normal Superior de Neiva) named after Peter McLaren in Neiva, Colombia. Source: Chapman University, https://blogs. chapman.edu/education/2017/08/24/teachers-collegebuilding-named-after-dr-peter-mclaren/. 
The comic genre necessitates condensation. Breaking Free's four-page preface precedes 103 autobiographical comicbook-style pages that are divided into eight periods. Part 1, "Early Life", wittily describes McLaren growing-up as an only child in a working-class neighbourhood in Toronto, before his father's career enabled the family to move to Winnipeg. Part 2, "Hippie Days" chronicles McLaren's hitchhiking through the U.S. as a young adult, looking for likeminded spirits who were also opposing the Vietnam War (or American War, as the Vietnamese call it).

Part 3, "College Days", is less about McLaren's studies at the University of Toronto in the early 1970s, and more about his solidaric sentiments with Black Panthers like Angela Davis and Malcolm $X$, and his being angered by the disproportionate number of people of colour being recruited in the infantry and sent to the front lines of the American War. Musical favourites were protest singers Woody Guthrie and Bob Dylan and blues musicians Robert Johnson and Muddy Waters.

"Teaching Days" (part 4) is only three pages short, while part 5 ("Working with the Corridor kids") is disproportionately long at 32 pages. The fourth chapter reconstructs McLaren's conscious decision to teach working-class students, having realised that parental wealth and social power were strongly correlated with student success and that he could have more impact working with underprivileged children. In chapter 5, McLaren narrates his experience of teaching students from grade two all the way to grade eight for five years. This was an extremely trying period of his life, as most of the kids were from poor, dysfunctional, often single-parent families, with their parents often holding two or even three jobs simultaneously to make ends meet and the children facing hardship at home and violence in the streets. Given the children's background, it is unsurprising, that he encountered rebellious students on an almost daily basis. During the first few weeks of his teaching in the JaneFinch Corridor, McLaren was faced with the decision "to change my entire approach or sacrifice my stomach" (p. 52). The teaching experience led to the publication of his first book, Cries from the Corridor (McLaren, 1980). The chapter ends with an illustration of Brazilian liberation theologian, Dom Hélder Câmara and his quote: "When I give food to the poor, they call me a saint. When I ask why they are poor, they call me a communist" (cited in p. 65). McLaren's first book provided a vivid description of the working class school in inner-city Toronto, but in his own analysis, it fell short in providing "an explanation for why those kids were so ferocious and a much deeper analysis of structural racism and class warfare in a capitalist society" (p. 65).

The drawing that starts off part six ("Graduate study") is clearly an homage to the poster for Stanley Kubrick's controversial A clockwork orange movie. One of the classic film posters of all time that shows a vicious-looking Malcolm McDowell wielding a glinting knife is transformed into Peter McLaren brandishing a giant pencil. To describe the character Alex (played by McDowell) as an enfant terrible would be an understatement, but in this chapter, McLaren certainly also has some shock value by focusing his own major theoretical influences on the seemingly contradictory duo of Marx and Jesus. After having grown up as an evangelical
Christian (McLaren, 2019), his Christian beliefs now appear to be much closer to Latin American liberation theology. In McLaren's interpretation, there is no contradiction between Christianity and Marxism, as "Jesus maintains an intransigent condemnation of the rich" (p. 68). McLaren's fascination with Marx is explained as follows:

\begin{abstract}
"Reading Karl Marx helped me question why the United States has the largest defence expenditures in the world, the highest level of economic inequality among developed countries, and the world's greatest per capita health expenditures... and, why - among developed nations - does the U.S. have the lowest life expectancy. Why does such a rich country have the lowest measures of equality of opportunity?" (p. 68).
\end{abstract}

References would be utterly misplaced in a comic book, but to my astonishment, some quick Google searches confirmed all the above claims. It may be added that many countries that are not classified as 'developing countries' may do worse in terms of economic inequality and life expectancy.

Part seven is titled "Professor days" and continues with meetings with major leftist theoreticians who influenced McLaren. A page each is dedicated to Paulo Freire and Antonia Darder (see my other book review in this JALT special issue: Rudolph, 2021), and this section is populated with many other leftist intellectuals that McLaren encountered and admires (including a powerful critique of the mass media by Noam Chomsky).

The section concludes with McLaren's work in Mexico, Central, and South America, some of it with indigenous communities. It once again shows that McLareen is quite an unusual Professor. While I am intrigued by McLaren's reinterpretation of critical pedagogy having to include learning "from our indigenous ancestors" (p. 81) and his support of indigenous people like the Rarámuri (in the Mexican state of Chihuahua), he also has more controversial associations. For instance, a meeting with the late Venezuelan autocrat Hugo Chávez (1954 - 2013) is uncritically narrated - and later in Breaking Free (p. 85) as well as in other writings, McLaren stated his very vocal support for Chávez (McLaren, 2019, 2021).

The final section, entitled "Days of Rage" has another intriguing cover image, this time McLaren replaces Argentine revolutionary Che Guevara. Days of Rage originally refers to a series of violent street protests organised by the Weathermen (a faction of Students for a Democratic Society) in October 1969 in protest against the Vietnam War. Another reviewer had also been puzzled by this title, as McLaren is non-violent and would not call for violent street protests (Whitcomb, 2020). However, McLaren has written about "critical rage" (2019) that would appear to be peaceful.

A surprising six pages in the book's final section are dedicated to McLaren's friend Joel Kovel, the colourful founder of eco-socialism, and his works. In 2014, McLaren became Distinguished Professor at Chapman University and 


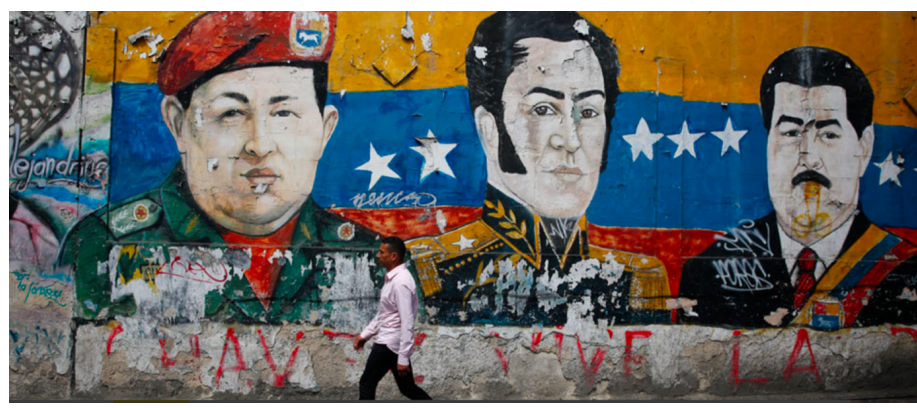

Figure 2: A Venezuelan mural with Hugo Chávez, Simón Bolívar (19th century-Venezuelan liberator and Latin American independence hero), and Nicolás Maduro. Source: Cuotto, 2020.

continues to work there with other Freirians for common goals (he was writing these lines, while Trump was still President):

\begin{abstract}
"We must fight fascism, anti-semitism, racism, ableism, sexism, homophobia and the coloniality of power at every turn... Right now is a crucial time to fight fascism all around the world and to save the planet from humans who deny climate change and destroy the biosphere on a regular basis" (pp. 95-96).
\end{abstract}

In the Epilogue, McLaren distances himself from the Soviet Union and "former Eastern Bloc police states", as they were "state capitalist" and not truly socialist (p. 101). The book ambiguously ends with the call to break free and rebuild the world.

Many readers will disagree with McLaren's politics. To choose but one example, I was disturbed by his silence on Chávez's autocratic rule, the latter's muzzling of the media and destruction of an independent judiciary as well as his corrupt, incompetent and dictatorial regime. While Chávez, in 1998, was elected President on his promise of poverty alleviation, the Bolivarian socialist soon turned autocrat and modelled Venezuela's political and economic system after Castro's Cuba. Chávez befriended dictators such as Saddam Hussein, Robert Mugabe, Muammar Qaddafi and Bashar Assad and his chosen heir Nicolás Maduro further impoverished the oil-rich country (The Economist, 2013a, b). Economic mismanagement and political repression led to an exodus of millions of Venezuelans - "the biggest movement of people in Latin America's recent history" - as well as hyper-inflation, increased infant mortality, food and medicine shortages and increased poverty (The Economist, 2018a, b, 2019). McLaren does not only have misplaced sympathies for Chávez's autocratic regime but also for communist Cuba.

Academic freedom of expression is an important ideal, and the author, this reviewer and readers may have to agree to disagree on some of McLaren's political thoughts. All in all, Breaking free: The life and times of Peter McLaren, radical educator offers an artistic retelling of the life and key works of McLaren and questions the reduction of education to

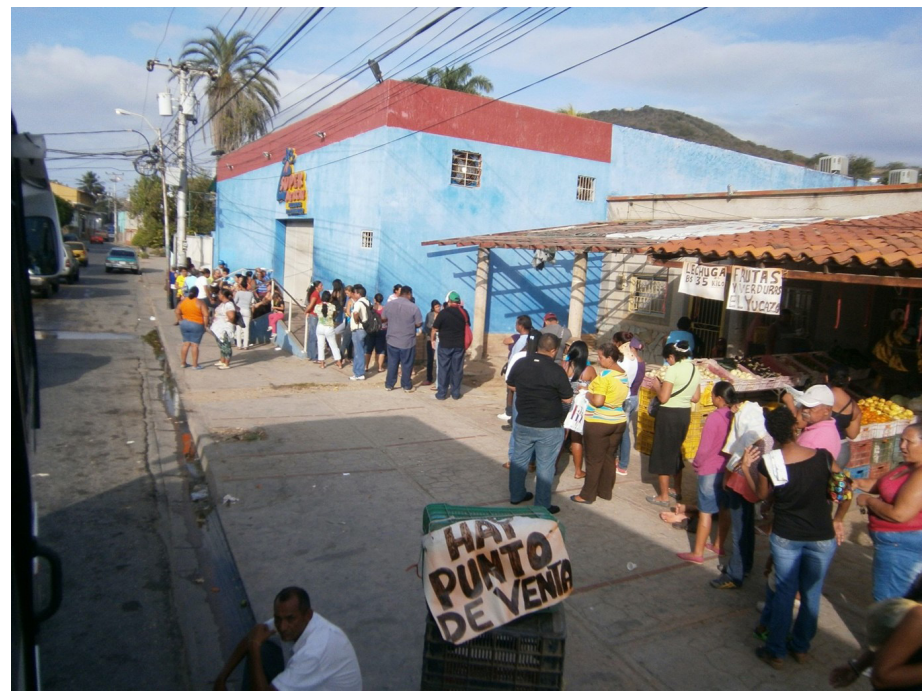

Figure 3: The consequences of chavismo. Shoppers queuing outside a store for government-subsidised products in March 2014. Source: Wilfredo. Creative Commons license CCO. https://en.wikipedia.org/wiki/Shortages_in_Venezuela\#/ media/File:Escasez_en_Venezuela,_Mercal.JPG

mere classroom practices. Peter McLaren has certainly lived an interesting life, and in line with the ethos of critical pedagogy, his work deserves a critical reading that avoids automaton conformity. This comic book presents as good an introduction as any to McLaren's massive oeuvre.

\section{Additional references}

Cuotto, V. (2020, March 4). mural-venezuela-maduro-chavezbolivar. Caracas Chronicles, https://www.caracaschronicles. com/2020/03/04/the-end-of-a-revolution-that-neverbegan/mural-venezuela-maduro-chavez-bolivar/

Fassbinder, S. D. \& McLaren, P. (2006, April 6). The "Dirty Thirty's" Peter McLaren reflects on the crisis of academic freedom. MR Online, https://mronline.org/2006/04/06/ the-dirty-thirtys-peter-mclaren-reflects-on-the-crisis-ofacademic-freedom/

Jandrić, P. (2018). Peter McLaren: Portrait of a revolutionary. Rassegna di Pedagogia, 76(1-2), 139-158. https://doi. org/10.19272/201802102010.

McLaren, P. (1980). Cries from the corridor. Methuen.

McLaren, P. (1993). Schooling as a ritual performance. Towards a critical economy of educational symbols \& gestures. Second edition. Routledge.

McLaren, P. (2003). Life in schools. An introduction to critical pedagogy in the foundations of education. Fourth edition. Pearson Education.

McLaren, P. (2019). God and governance: reflections on living in the belly of the beast. Postdigital Science and Education. https://doi.org/10.1007/s42438-019-00050-1 
McLaren, P. (2021).The perilous road to justice: An interview with Peter McLaren. Journal of Higher Education Policy And Leadership Studies, 2(1), 145-156. DOI: https://dx.doi. org/10.29252/johepal.2.1.145

McLaren, P., \& Jandrić, P. (2014). Critical revolutionary pedagogy is made by walking: In a world where many worlds coexist. Policy Futures in Education, 12(6), 805-831. https:// doi.org/10.2304/pfie.2014.12.6.805.

Rudolph, J. (2021). Book Review of Darder, Antonia (2018). The student guide to Freire's pedagogy of the oppressed. Bloomsbury. Journal of Applied Learning and Teaching, 4(Sp. Iss. 1), 1-4. DOI: https://doi.org/10.37074/jalt.2021.4.s1.7

The Economist. (2013a, March 9). Hugo Chávez's rotten legacy. https://www.economist.com/leaders/2013/03/09/ hugo-chavezs-rotten-legacy

The Economist. (2013b, March 13). Now for the reckoning. https://www.economist.com/briefing/2013/03/09/now-forthe-reckoning
The Economist. (2018a, August 25). A rude reception awaits many Venezuelans fleeing their country. https:// www.economist.com/the-americas/2018/08/25/a-rudereception-awaits-many-venezuelans-fleeing-their-country

The Economist. (2018b, August 25). Nicolás Maduro tries to rescue Venezuela's economy. https://www.economist.com/ the-americas/2018/08/23/nicolas-maduro-tries-to-rescuevenezuelas-economy

The Economist. (2019, January 25). Why have Venezuelans turned against Nicolás Maduro? https://www.economist. com/graphic-detail/2019/01/25/why-have-venezuelansturned-against-nicolas-maduro

Whitcomb, C. (2020). Review of Peter McLaren (2019). Breaking Free: The Life and Times of Peter McLaren, Radical Educator. Illustrated by Miles Wilson. Postdigital Science and. Education, 2, 525-529. https://doi.org/10.1007/s42438-01900061-y

Copyright: @ 2021 Jürgen Rudolph. This is an open-access article distributed under the terms of the Creative Commons Attribution License (CC BY). The use, distribution or reproduction in other forums is permitted, provided the original author(s) and the copyright owner(s) are credited and that the original publication in this journal is cited, in accordance with accepted academic practice. No use, distribution or reproduction is permitted which does not comply with these terms. 